\title{
放射温度による無次元蒸発散量の評価について
}

\author{
山田 優 $* \dagger \cdot$ 木村玲二 $* *$ ・杉村芙美子 $* * *$ ・神近牧男 $* * * *$ \\ $\left(\begin{array}{c}* \text { 株式会社三祐コンサルタンツ } \\ * * \text { 鳥取大学乾燥地研究センター } \\ * * * \text { 沖縄日立ネットワークシステムズ株式会社 } \\ * * * * \text { 鳥取環境大学 }\end{array}\right)$
}

\section{Evaluation for Non-Dimensional Evapotranspiration with Radiometric Surface Temperature}

Yu YAmadA*†, Reiji KIMURA**, Fumiko SugIMURA***, and Makio KAMICHIKA****

*Sanyu Consultants Inc., Naka-ku Nishiki 2-15-22, Nagoya 451-0003 Japan

**Arid Land Research Center, Tottori University, Hamasaka 1390, Tottori 680-0001 Japan

***Okinawa Hitachi Network Systems Ltd., Nishi 1-19-7, Okinawa 900-0036 Japan

****Tottori University of Environmental Studies, Wakabadai Kita1-1-1, Tottori 689-1111 Japan

\begin{abstract}
Relationship between the index with radiometric surface temperature and ratio of actual evapotranspiration $(E T)$ to potential evaporation $E_{p}$ (=non-dimensional evapotranspiration) was examined in the indoor and field experiment. Index corresponded to the change of $E T / E_{p}$. Also, index was related to the leaf water potential and volumetric soil water content within the root zone.
\end{abstract}

Key words: Evapotranspiration, Radiometric surface temperature, Water potential キーワード : 蒸発散量, 放射温度, 水ポテンシャル

\section{1.はじめに}

近年，リモートセンシング技術は蒸発散量や土壌表層 の水分量の推定, 水分ストレスの同定等に幅広く使用さ れている。特に作物栽培において, リモートセンシング技 術は病害虫や水分不足などによるストレスの早期発見, ま たは潅水計画に必要な蒸発散量の評価に対して有効であ ると考えられる。

本研究では, 群落面で計測した放射温度とバルク式で 推定した空気力学的温度を組み合わせた指標を提示し, 指標と無次元蒸発散量 ( 実蒸発散量とポテンシャル蒸発 量の比) の関係, および指標と葉内水ポテンシャル, 土 壌体積含水率の関係について検討した。

2006 年 4 月 19 日 受付, 2006 年 6 月 8 日 受理

${ }^{\dagger}$ Corresponding Author: E-mail: rkimura@alrc.tottori-u.ac.jp

\section{2. 研究方法}

\section{1 指標の概要}

群落面の温度変化に影響を与える要因として, 植物の 生理的要因である気孔の開閉, 外的要因である葉面の 放射収支・熱収支, 土壌水分, 植被率などが挙げられ る。本研究では放射収支や熱収支の影響を除去するため に, Idso et al. (1981) による Crop Water Stress Index (CWSI) を参考にした以下の指標を提示する。

$$
I_{s}=\frac{T_{L}-T_{\min }}{T_{\max }-T_{\min }}
$$

ここに, $T_{L}$ は群落面温度 $(\mathrm{K})$ である。 $T_{m i n}$ は蒸発散が 盛んな時の群落面温度 $(\mathrm{K}), T_{\max }$ は蒸発散が停止した状 態における群落面温度 $(\mathrm{K})$ と仮定する。

$I_{s}$ の算定に必要な $T_{\max }, T_{\text {min }}$ は, 以下のように推定した。 まず，植物群落における熱収支式は次式で表される。

$$
R^{\downarrow}-G=\varepsilon \sigma T_{s}^{4}+l E+H
$$




$$
R^{\downarrow}=(1-r e f) S^{\downarrow}+L^{\downarrow}
$$

ここに, $R$ はは有効入力放射量 $\left(\mathrm{Wm}^{-2}\right), \mathrm{G}$ は地中伝導 熱フラックス $\left(\mathrm{Wm}^{-2}\right), \varepsilon$ は射出率 (本研究では 0.98 と 仮定 $), \sigma$ はステファン・ボルツマン定数 $\left(=5.67 \times 10^{-8}\right.$ $\left.\mathrm{Wm}^{-2} \mathrm{~K}^{-4}\right), T_{s}$ は群落面温度 $(\mathrm{K}), H$ は顕熱フラックス $\left(\mathrm{Wm}^{-2}\right), l E$ は潜熱フラックス $\left(\mathrm{Wm}^{-2}\right), r e f$ はアルベド, $S^{\downarrow}$ は全天日射量 $\left(\mathrm{Wm}^{-2}\right), L^{\downarrow}$ は下向き長波放射量 $(\mathrm{Wm}$ ${ }^{-2}$ )である。

$H, l E$ は次のバルク式で表される。

$$
\begin{aligned}
& l E=c_{P} \rho C_{H} U\left(T_{s}-T\right) \\
& l E=l \rho \beta C_{H} U\left\{q_{\text {sat }}\left(T_{s}\right)-q\right\}
\end{aligned}
$$

ここに, $c_{P}$ は定圧比熱 $\left(\mathrm{Jkg}^{-1} \mathrm{~K}^{-1}\right), \rho$ は空気の密度 $\left(\mathrm{kgm}^{-3}\right), C_{H}$ はバルク係数, $U$ は風速 $\left(\mathrm{ms}^{-1}\right), T$ は気 温 $(\mathrm{K}), l$ は蒸発潜熱 $\left(\mathrm{Jkg}^{-1} \mathrm{~m}^{-3}\right), \quad \beta$ は蒸発散効率, $q_{\text {sat }}$ $\left(T_{s}\right)$ は表面温度 $T_{s}$ に対する飽和比湿 $\left(\mathrm{kgkg}^{-1}\right), q$ は比湿 $\left(\mathrm{kgkg}^{-1}\right)$ である。

$G$ は, Allen et al.(1998) による次式を用いて算定した。

$$
G=0.1\left(R^{\downarrow}-\varepsilon \sigma T_{s}^{4}\right)
$$

$$
\begin{gathered}
\text { 式(2)〜 (6) より次式が得られる。 } \\
R^{\downarrow}-G-\varepsilon \sigma T_{s}^{4}-c_{P} \rho C_{H} U\left(T_{s}-T\right) \\
-l \rho \beta C_{H} U\left\{q_{s a t}\left(T_{s}\right)-q\right\}=0
\end{gathered}
$$

$\beta$ が 1 のときは群落面が十分に湿っている状態を示し, 0 は完全に乾燥している状態を示すと仮定される。した がって, 式(7)に扔いて, $\beta=1,0$ の場合の左辺が 0 に 収束する $T_{s}$ を逐次近似によって算定し, $T_{\min }, T_{\text {max }}$ を求めた。

本研究では, 式 (1)で算定された $I_{s}$ と無次元蒸発散量 $E T / E_{P}$ (実蒸発散量とポテンシャル蒸発量の比) の比較を 室内実験および屋外実験にて行った。ポテンシャル蒸発 散量 $E_{P}$ は, Kondo and Xu (1997) で提示されたもので, 仮想的な地表面からの蒸発量と定義される。また, 屋外 実験では $I_{s}$ を蒸発散量と関わりの深い葉内水ポテンシャ ルや土㙵体積含水率とも比較した。

\section{2 室内実験の概要}

鳥取大学乾燥地研究センター内の人工気象室とビニ ルハウスにおいて, 供試植物にコウシュンシバ (Zoysia matrella)を用い, 1/2000 a のワグネルポットに栽植して 室内実験を行った。人工気象室での観測は, 2005 年 6 月 24 日から 7 月 20 日までの 27 日間行い, ビニルハウ スでの観測は, 2005 年 10 月 16 日から 11 月 15 日まで の 31 日間行った。

ワグネルポットには鳥取砂丘砂を乾燥密度 $1.4 \mathrm{gcm}^{-3}$
程度になるように詰め, 土㙵水分量は, 圃場容水量 ( 体 積含水率 $\left.\theta\left(\mathrm{m}^{3} \mathrm{~m}^{-3}\right)=0.08\right)$, 初期しお扎点含水率 $(\theta=$ $0.03)$ となるように調製した。以降, 日々の観測開始時の 土壌水分量を戋場容水量としたポットを灌水区, 初期しお れ点含水率としたポットをストレス区と称する。人工気象 室の実験では灌水区, ストレス区を各 2 ポットずつ, 計 4 ポットを用いた。ビニルハウスでの観測では, 灌水区, ス トレス区を各 3 ポットずつ, 計 6 ポットを用いた。水分欠 そによるストレスのみをシバに与えるために，各ポットの 蒸発散によって減少した水分量を日々の測定後に灌水し 補充した。

測定項目は, 群落面温度 (本研究では, ポット内の シバの平均葉面温度を群落面温度と仮定した), 蒸発散 量, 気温, 相対湿度, 正味放射量である。群落面温度 の測定は放射温度計 (日本電子; JTG-5700) で天底角 $70^{\circ}$, 視野角 $30^{\circ}$ に設定して行った。天底角を $70^{\circ}$ にした 理由として, この角度で測定された放射温度が空気力学 的温度にほぼ等しくなるという結果に基づいているためで ある (Matsushima and Kondo, 1997)。蒸発散量は観 測開始直前と直後でポットの重量を測定することによって 求めた。人工気象室内の気象条件は, 風速 $1.0 \mathrm{~ms}^{-1}$, 気 温 $28^{\circ} \mathrm{C}$, 相対湿度 $50 \%$, 照度 80,000 lux となるように 設定した。人工気象室の実験では, 気象要素, 群落面温 度の測定はシバの蒸散が盛んとなる時間帯の 10 時から 16 時まで (ビニールハウスの実験では 10 時から 14 時ま で 10 分ごとに行った。観測時間帯には常に風速は 1.0 $\mathrm{ms}^{-1}$ となるように市販の扇風機を用いた送風を行った。

\section{3 屋外実験の概要}

観測は, 乾燥地研究センター内砂丘砂戋場で, 2005 年 8 月 20 日から 8 月 31 日までのうち晴天日 9 日間に行つ た。固場内には, 実験区を二つ設定した。測定期間中の 毎日朝夕に灌水を行う灌水区 (1.92 ha) と, 灌水を行わ ないストレス区 $(0.5 \mathrm{a})$ を設定した。供試植物には, 青刈 り用ダイズ (Glycine max (L.) Merrill)を用いた。各処 理区のダイズの栽植密度は $1 \mathrm{~m}^{2}$ あたり灌水区で 46.8 本, 水ストレス区で 54.8 本であった。観測期間の植被高は $40 \mathrm{~cm}$ から $45 \mathrm{~cm}$, LAI (葉面積指数) は 2 から 3 に変 化した。測定項目は気温, 相対湿度, 放射量, 風速, 群 落面温度, 土㙵水分量, 葉内水ポテンシャルである。群 落面温度は, 室内実験と同様の測器を用い, 天底角, 視 野角も同じように設定した。土壌水分量は, 各実験区 2 点ずつ TDR 土壌水分計 (Campbell; CS615) を鉛直に 地面に挿して深度 $0 \sim 30 \mathrm{~cm}$ の土層の平均体積含水 率 $\theta$ を測定した。なお, この深度の土層では根の密集が 確認された。気象要素, 群落面温度, 土㙵体積含水率の 測定は 10 時から 14 時まで 10 分ごとに行った。葉内水 
ポテンシャルはプレッシャーチャンバー(PMS Instrument Company; PMS Model 1000)で, 14 時に測定した。灌 水区の蒸発散量にはボーエン比法によって測定した值を 用い, ストレス区では土壌水分量の減少量から算出した。

\section{4 バルク係数の設定}

本研究では顕熱・潜熱フラックスを表わす際にバルク式 を用いているが，式中にあるバルク係数 $C_{H}$ またはバルク 輸送係数 $C_{H} U$ を知ることが必要である。室内実験では以 下のようにバルク係数の算定を行った。まず，式(5)に示 される潜熱フラックス $l E$ の式に蒸発散量の観測值および 気象データを代入する。 $C_{H} U$ を算出する際の条件として, 灌水区, ストレス区ともに霧吹きで, 群落面を十分に湿ら せ, 遮断蒸発を起こすことにより, 蒸発散効率 $\beta$ を 1 とし た状態で行った。

屋外実験では次のようにしてバルク係数の算定を行った。 一般的に $C_{H}$ は大気安定度を考慮して算定するが, 今回 は大気安定度を中立と仮定し, 次の式によって求めた。

$$
C_{H}=\frac{k^{2}}{\ln \left\{(z-d) / z_{0}\right\} \ln \left\{(z-d) / z_{T}\right\}}
$$

ここに, $k$ はカルマン定数 $(\fallingdotseq 0.4), z$ は風速と気温の 測定高度 $(\mathrm{m}), d$ は地面修正量 $(\mathrm{m}), z_{0}, z_{T}$ はそれぞれ 風速, 気温に対する粗度長 $(\mathrm{m})$ である。 $d, z_{0}, z_{T}$ につ いては, 経験的に以下のように表わすことができる (Allen et al., 1998)。

$$
\begin{aligned}
& d=2 / 3 h \\
& z_{0}=0.123 h \\
& z_{T}=0.1 z_{0}
\end{aligned}
$$

ここに, $h$ は植被高 $(\mathrm{m})$ である。

\section{3. 結果および考察}

Fig. 1 に人工気象室での $I_{s}$ と無次元蒸発散量 $E T / E_{P}$ と の関係を, Fig. 2 にビニルハウスでの $I_{s}$ と $E T / E_{P}$ との関 係を示す。一般に植物は水分欠乏などのストレスを受ける と体内の水分を保持するために蒸散を抑制する。したがつ てストレスを受けた植物の蒸発散量は, 十分に水を与えら れて生育した植物よりも少なくなる。このことは Fig. 1 の 灌水区では $E T / E_{P}$ が大きく, $I_{s}$ は小さな值を示し, 逆に ストレス区では $E T / E_{P}$ が小さく, $I_{s}$ が大きな值を示した様 子から判断できる。Fig. 2 に拈いても, 灌水区のプロット はストレス区に比べ, $E T / E_{P}$ が大きく, $I_{s}$ は小さくなるよ うに分布した。また Fig. 1, 2 ともに, $I_{s}$ と $E T / E_{P}$ との関 係は負の相関を示した (Fig. 1 では相関係数 $\mathrm{R}=-0.81$,
Fig. 2 では $\mathrm{R}=-0.72)$ 。なお, 人工気象室, ビニール ハウスの実験では, 同じ植物を用いたにも関わらず， $I_{s}$ と $E T / E_{P}$ との間の勾配が異なっている。人工気象室ではほ ぼ気象条件が一定, ビニールハウスでは気象条件が変化 するため, 同じ芝を用いても異なる生理状態を示したと考 えられる。たとえば，人工光と自然光に対する気孔抵抗や 蒸散速度の違いなどが考えられる。Fig. 3 にダイズ戋場 での $I_{s}$ と $E T / E_{P}$ との関係を示す。屋外圃場の測定におい ても灌水区の $E T / E_{P}$ はストレス区のものに比べ大きく, $I_{s}$ は小さな值をとるように分布した。加えて, $I_{s}$ と $E T / E_{P}$ の 間には有意な負の相関が認められた。

Fig. 4 にダイズ固場での $I_{s}$ と $\Psi_{L}$ (葉内水ポテンシャル ) との関係を示す。水ストレスを受けた植物の $\Psi_{L}$ は, 健 康な状態よりも值が低下する。両区の $I_{s}$ と $\Psi_{L}$ との関係に は負の相関関係が見られた。ダイズは $\Psi_{L}$ が $-1.0 \mathrm{MPa}$ 以下になると蒸散速度が低下することが知られている (Boyer, 1970)。図より， $\Psi_{L}$ の低下が，蒸散抑制による

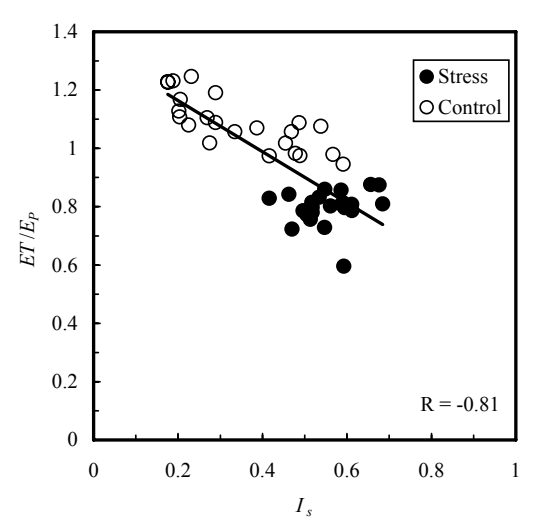

Fig. 1. Relationship between $I_{s}$ and $E T / E_{P}$ in the chamber experiment.

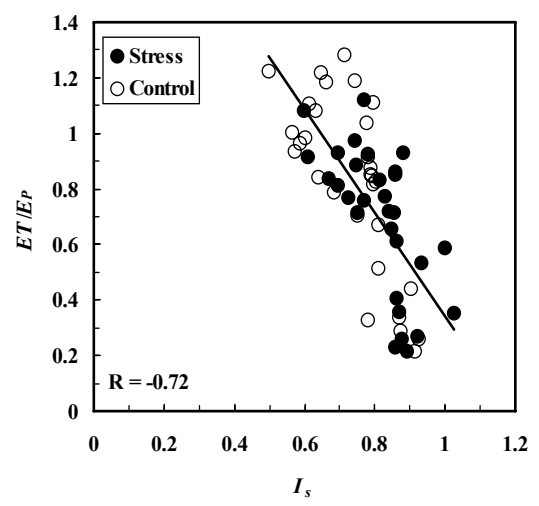

Fig. 2. Relationship between $I_{s}$ and $E T / E_{P}$ in the greenhouse experiment. 


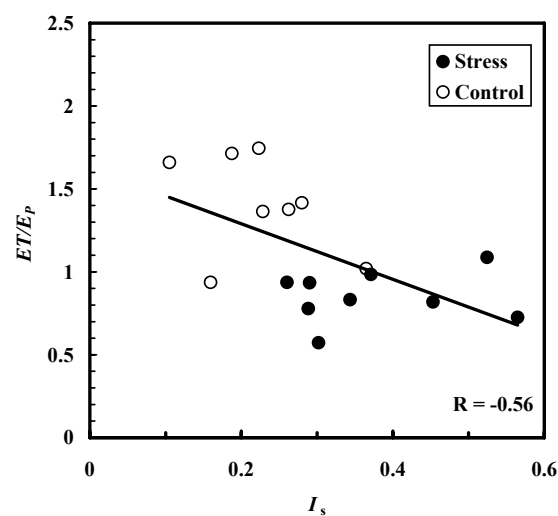

Fig. 3. Relationship between $I_{s}$ and $E T / E_{P}$ in the soybean field.

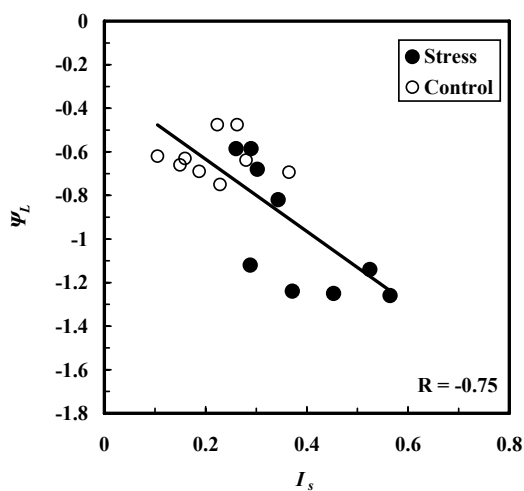

Fig. 4. Relationship between $I_{s}$ and leaf water potential in the soybean field.

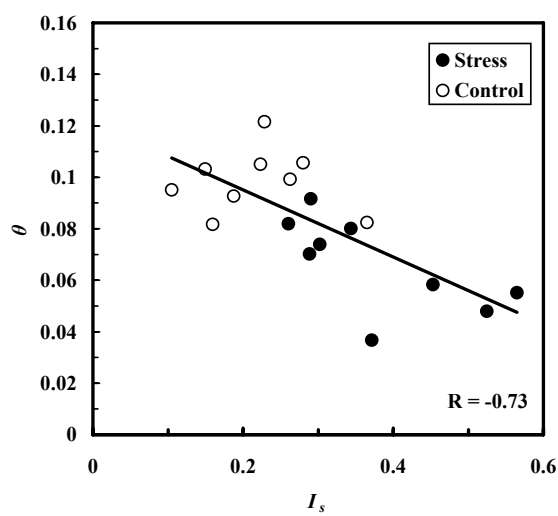

Fig. 5. Relationship between $I_{s}$ and soil moisture content in the soybean field.

群落面温度の上昇とほぼ同時に検出されたことが理解で きる。

Fig. 5 にダイズ围場での $I_{s}$ と $\theta$ との関係を示す。観測
期間後半には晴天日が続き, 鳥取砂丘砂の初期しおれ点 含水率である 0.028 (Inoue and Nomura, 1983) 付近ま で $\theta$ が低下する日が見られた。これらの日の $I_{s}$ は高い值 を示したことから, 土壌水分量が低下した場合には, 植 物は吸水を十分に行うことができず，ストレスを受け，そ のため蒸散を抑制し, それに伴う群落面の温度上昇が見 られたと考えられる。一方, 十分な土壌水分量があった 圃場容水量以上の場合, $I_{s}$ は低い值を示した。 $I_{s}$ は土壌 水分量の減少に伴う吸水不足による群落面温度の上昇も 検出していたことが分かる。

\section{4.まとめ}

本研究では, 放射温度計から得られる群落面温度とバ ルク式で推定した空気力学的温度を組み合わせた指標を 提示し, 指標と無次元蒸発散量の関係, および指標と葉 内水分ポテンシャル, 土壌体積含水率の関係について検 討した。

室内実験において, 本研究で提示した指標 $I_{s}$ と無次元 蒸発散量 $E T / E_{P}$ とを比較した結果, $I_{s}$ と $E T / E_{P}$ の間には 負の相関が見られた。屋外圃場での観測においても， $I_{s}$ と $E T / E_{P}$ との間に有意な負の相関が認められた。他にも $I_{s}$ と葉の水ポテンシャル $\Psi_{L}$, 土壌体積含水率 $\theta$ と優位な 相関が認められた。

今後の展望として, 人工衛星から得られる地表面温度 と, 地上の気象観測所などから得られる気象観測データ から $I_{s}$ を算出し, より広域な植物群落のストレス評価を行 うことが期待される。現在, 中国黄土高原の小流域 (約 $\left.10 \mathrm{~km}^{2}\right)$ に本指標を適用している段階であり, 草地にお ける $I_{s}$ と $E T / E_{P}$ との間の決定係数は 0.874 , 標準誤差は 0.103 となっている。

\section{References}

Allen, R. G., Pereira, L. S., Raes, D., and Smith, M., 1998: Crop evapotranspiration: Guidelines for computing crop water requirements. FAO, Rome, 300pp.

Boyer, J. S., 1970: Differing sensitivity of photosynthesis to low leaf water potentials in corn and soybean. Plant Physiol., 46, 236-239.

Idso, S. B., Jackson, R. D., Pinter, P. J., Reginato, R. J., and Hatfield, J. L., 1981: Normalizing the stress-degree-day parameter for environmental variability. Agric. Meteor., 24, 45-55.

Inoue, M., and Nomura, Y., 1983: Laboratory determinaion of dune sand water constants and soil water characteristic curve during the drying 
process, Sand Dune Research, 30, 15-25.

Kondo, J., and Xu, J., 1997: Potential evaporation and climatological wetness index. Tenki, 44, 875883.

Matsushima, D., and Kondo J., 1997: A proper method for estimating sensible heat flux above a horizontal-homogeneous vegetation canopy using radiometric surface observations. J. Appl. Meteorol., 36, 1696-1711. 